Irina Saukh, Doctor of Economics, professor Zhytomyr State University named after Ivan Franko Ukraine, Zhytomyr ORCID: 0000-0002-3812-6579

Victoriia Shimanskaya, Ph. D. Zhytomyr branch of «Kiev Institute of Business and Technology», associate Professor Ukraine, Zhytomyr, ORCID: 0000-0003-0734-0721

ResearcherID: G-5573-2019

Tetiana Momont, Ph. D. Zhytomyr branch of «Kiev Institute of Business and Technology», associate Professor of the Department of Economics and entrepreneurship

Ukraine, Zhytomyr, ORCID: 0000-0002-6371-599X

\title{
CREATIVE MANAGEMENT AS A NEW PARADIGM IN TOURISM
}

The article describes the sense of creative management as a new management paradigm that is related to the introduction of humanistic and social technologies as well as to the models of management activity. The article formulates goals of creative management for tourism business. It also investigates the problem of implementation of the creative management system in the practice of management activity in the tourism industry in the realities of modern Ukraine. Emphasis is placed on the need to build a highly efficient tourism industry, which is intended to play a role of driver for the national economy.

Keywords: creativity, creative management, creative management of tourism business.

Relevance of the research topic. Modern era of global social transformations and experience of economically developed countries of the world leads to the conclusion that nowadays current economic development is determined by successful management and highly professional managers. Moreover, effectiveness of the activities, industries, organizations is largely determined by the ability of the enterprise manager to strategically generate important decisions, that then materialize into a variety of managerial, social, industrial innovations. This is especially true for the domestic tourism industry. 
Formulation of the problem. The problems of implementation of creative management system in the practice of tourism management, unfortunately, do not occupy a significant place in the studies of domestic scientists, economists and practitioners. The complex political and economic conditions, in which the tourism industry of Ukraine has been developing, have revealed systemic problems accumulated in previous years, that hinder the growth of the industry [3].

In this situation, creative management could allow Ukrainian tourism to reach a competitive level of public economy, increase the production pace of a competitive tourism product, and modernize the motivational foundations of tourist enterprises. This raises the issue of in-depth research into the problems of new transformational changes in the system of managerial relations in the post-industrial economy.

Analysis of recent research and publications. Important contribution to the study of the problem of creative management was made by domestic scientists, in particular: I.I. Svidruk, B.V. Litovchenko, T.V. Bozhidarnik, S.S. Holasyuk, T.I. Tkachenko, O.I. Klipkova, O.P. Pashchenko, O.V. Kalyuzhna, N.V. Savitskaya. The theory of creativity is reflected in the writings of scientists J. Guilford, K. Matsushita, K. Nordstrom, J. Ridderstral, R. Sternberg, P. Torrens and others. The overwhelming majority of scientists-researchers of the tourism industry consider the following as main problems: outdated material and technical base, technological gap, insufficient level of staff qualification, imbalance of prices and quality of services as well as imperfect legal support of the activity of tourism business.

At the same time, paying due attention to the work of scientists in this discourse of science, it should be noted that the concept of creative management, in the tourism industry in particular, lacks a clear design and well-established content. This means that some questions remain open and debatable.

Setting objectives. The purpose of this article is to study main theoretical aspects of creative management, its influence on the development of tourism business in Ukraine and the need to use tools in the management activities of modern business in tourism industry.

Presenting main material. The era of economy of knowledge (economic development is based on intellectual property, intangible assets) in the developed countries is changing to the creative or innovative economy (the leading role in the development of society is taken by new ideas and innovations), given that the creative potential of the economy is at the forefront of economic development. In fact, the main difference between creative management and traditional administration is that the latter is based on the fulfillment of job descriptions, established rules, standards by staff, whereas creative management is a natural result of innovative and creative management revolution of the early XXI century.

Under creative management we understand such managerial actions towards the personnel of the organization that are aimed at maximum disclosure of latent abilities 
of employees, use of their creative potential and initiative in order to create new, competitive ideas, products, services. Thus, creative management is management of 1) new ideas (here is the intersection with innovative management) regarding products and services as well as 2) ensuring the conditions of creative abilities realization of the personnel. It is no coincidence that under these conditions the composition of management tasks changes $[7 ; 109]$ as well as the established character of manager's behaviour boundaries and the area of managerial decision-making. Moreover, professional managerial qualification is being restructured as well as the functionalpragmatic target of narrow-profile management activity is transformed into strategic, creative managerial competence.

Needless to say, this transformation in the world history of managerial activity did not occur over the night. It is important to emphasize that F. Taylor's scientific management emerged at the turn of the nineteenth and twentieth centuries as a result of his steadfast search for ways to improve production efficiency. He proposed «principles of scientific management» that led to the replacement of authoritarian methods of management with more rational scientific approaches. Management concepts of the first half of the twentieth century formalized the role of the manager in the organization (duties, functions), and reduced the management itself to mechanisms of administrative influence.

The beginning of orientation on the standards of creative management was laid by T. Peters and R. Waterman (consulting firm McKinsey) in the well-known concept of seven $\mathrm{S}$, which described the management of the following basic elements strategy, structure, amount of skills and competencies, management style, staff composition, common values and system of internal processes organization.

This concept did not only systematize traditional approaches to basic management concepts, but also pointed to the link between production processes and their contractors. A further step in the search for models of effective management was the concept of the socalled «collective wisdom» of K. Matsushita, in which the business leader of Japan in the twentieth century proclaimed that «business is people» [6].

At the end of the twentieth century K. Nordstrom and J. Ridderstral in the book «Business in the funk style» noted the following: 1) an era, in which the alarm system is constantly working, has come; 2) the future competitiveness is determined not by the current rules, but solely by the ability to break and change them; 3 ) the main trend is to focus on new ideas and creative staff of organizations [1]. Thus, we can say with confidence that at the turn of the XX - XXI centuries the continuous progress of creative management is caused by objective laws of economic development. It is at this stage that the tourism industry, both in the global context and in Ukraine, plays an increasingly prominent role and, undoubtedly, objectively has every reason to play the role of national economy driver. 
The tourism in many countries of the world is becoming a priority of economic development, not only in view of its dynamism and high profitability [2, 135], but also due to its significant positive socio-economic and cultural impact.

The low efficiency of the tourism industry in Ukraine is largely due to both the complexity and turbulence of the external conditions and the problems of the internal environment of the industry, in particular (a) the lack of proper government regulation and financing of the tourism sector in recent years; (b) lack of public monitoring and public reporting as a result of the reorganization of the state tourism management system; (c) unfavourable investment climate; (d) the misuse of tourism resources and related infrastructure; (e) low social and environmental performance of the tourism product; (h) imperfect statistical reporting and information support for the development of the country's tourist and recreational complex.

At the same time, it should be noted that Ukraine is an attractive region with its rich natural climatic, cultural, historical and national-ethnographic resources creating favourable conditions for the development of many types of tourism. Diversity of tourism resources provides an opportunity to enter the tourism market with unique and attractive offers. Such resources as historic monuments, architecture, religious and cultural sites, ethnographic features of the territory, authenticity of folk customs and traditions, occupy an important place in the development of domestic tourism. Assessment of the tourism potential and recreational resources gives grounds to say that Ukraine has significant prospects for the development of the tourism industry.

However, the current status of the industry with its low economic efficiency, does not correspond to the domestic potential of tourist and recreational resources. The following data indicate the unstable dynamics of tourist flows.

Table

\section{Number of foreigners crossing the state border of Ukraine, in thousands of people [8]}

\begin{tabular}{|l|c|c|c|c|c|c|c|}
\hline \multirow{2}{*}{2016} & \multirow{2}{*}{2017} & \multirow{2}{*}{2018} & \multirow{2}{*}{2019} & \multicolumn{3}{|c|}{ Increase, \% } \\
\cline { 6 - 8 } & & & & & $17 / 16$ & $18 / 17$ & $19 / 18$ \\
\hline I quarter & 2427,3 & 2631,5 & 2547,7 & 2357,8 & 8,4 & $-3,2$ & $-7,5$ \\
\hline II quarter & 3392,7 & 3697,1 & 3673,4 & 3513,8 & 9,0 & $-0,6$ & $-4,3$ \\
\hline III quarter & 4559,5 & 4769,5 & 4935,7 & - & 4,6 & 3,5 & - \\
\hline IV quarter & 3226,3 & 3323,1 & 3050,1 & - & 3,0 & $-8,2$ & - \\
\hline Total & 13606,0 & 14421,2 & 14207,0 & - & 6,0 & $-1,5$ & - \\
\hline
\end{tabular}

One of the most likely options for making positive changes in Ukrainian tourism with regard to its European integration and common civilizational priorities, given the complex socio-economic and geopolitical situation, is the transformation of 
traditional systems and management mechanisms, which, unfortunately, remain insufficiently effective.

Therefore, given the current trends in economic development, creative management for tourism business is emerging as a new management paradigm that is related to the implementation of humanistic, social technologies and models of management activity so much needed for the continuation of such economic development. Nowadays the demand for creative management is also driven by the fact that all known standard approaches, tools for solving management problems, working algorithms, methods, techniques, tools of traditional (administrative) management have already exhausted their reserves of economic growth, efficiency improvement and competitiveness of the tourism industry.

Content analysis of the economic literature has allowed to form such prerequisites for the emergence of creative management as a new management paradigm: 1) inefficiency of existing managerial methods based solely on managing the internal / external environment of the enterprise; 2) post-industrial economy, which requires new managerial tools, including methods of dealing with large volumes of unstructured information; 3) shift of emphasis from analysis and control of the past to analysis and control of the future; 4) increase of organizations flexibility needed for their adaptation to changes in the external environment; 5) increase of the competition in the markets; 6) complication of managerial systems, which requires their internal coordination.

Creative management in tourism contains such characteristics that have to be a real mainstream in management activities, whereas they are very difficult to implement in reality. A specific, well- and clearly defined as well as presented in a discrete, clear, unambiguous terms management object is an important characteristic of creative management.

The above allowed us to formulate the following goals of the creative management for tourism business: 1) assessment of individual's creative potential; 2) formation of creative atmosphere in the team; 3) formation of experts group to evaluate the proposals, in particular with regard to innovation policies aimed at improving the situation and preventing crises that may occur with tourism business; 4) formation of temporary creative teams of specialists capable to effectively participate in the creative teamwork; 5) evaluation of dominant motivational attitudes; 6) definition of heurism, operations and techniques required for better and more prompt creative delivery by specialists who are part of temporary creative teams.

As a consequence, generation of new ideas and finding of new solutions in order to achieve unique competitive advantage, efficiency and effectiveness in tourism business should be the strategic goal of creative management in tourism. 
Taking into account that such a concept of modern management (creative management) is a reflection of new boundaries of managerial activity, the problem of theoretical and methodological definition of its essence and tools of practical realization substantiation for the tourism industry arises. In tourism, creative result should come out of creative management, and creative managerial decisions, new ideas that ensure efficiency and profitability of a new, competitive tourism product as well as a significant socio-economic effect for the country, should be the product of the creative manager's work.

Conclusions. In today's economic conditions of instability and permanent crisis phenomena, the problem of developing and introducing new models of managerial activity in tourism arises inevitably. The conducted research has proven the importance of implementing the transition from administration to creative management, that foresees productive behaviour in situations of novelty and uncertainty, and undoubtedly becomes a prevailing trend on the basis of the new principle of internal harmonization of managerial relations.

Existing scepticism towards creative management can only be justified by the fact that everything «new» is at first unacceptable. The author proposes the use of a method of divergence, that involves extending the boundaries of the subject matter in order to provide sufficient space to find an effective solution. In addition, one should realize that creativity is neither a «seal of genius», nor a unique property of management. It is rather a complement to management, which, unfortunately, is very often equal to zero.

Therefore, the theoretical basis for the evaluation of the creative management value in the tourism industry should further constitute a basis for the study of the practical implementation level of creative management activity concept in tourism business. In this regard, developing a strategy for the totality of creative management, taking into account the problems and hidden opportunities of the tourist markets, based on the results of the study.

\section{REFERENCES}

1. Biznes $\mathrm{v}$ stile fank: kapital plyashet pod dudku talanta . K. Nordstrem, Y.Ridderstrale. Stokgol'mskaya shkola ekonomiki v Sankt-Peterburge. - 5-ye izd., ispr. - SPb., 2005279 s.

2. Vdovichen A., Tkachenko T. Upravlinnya turystychnym biznesom: innovatsiynyy pidkhid. (S. 134-138.) // Suchasnyy stan ta perspektyvy rozvytku turyzmu: Materialy mizhnarodnoyi naukovo-praktychnoyi konferentsiyi//Chernivtsi/ 2-4 travnya 2018. 287 s. 
3. Halasyuk S.S. Problemy upravlinnya sferoyu turyzmu Ukrayiny v umovakh s'ohodennya / S.S. Halasyuk // Trendy ta innovatsiyi v suchasniy ekonomitsi: materialy VII mizhnar. nauk.-prakt. konf., 23-24.04.2015 r. - Kharkiv: Kharkivs'kyy natsional'nyy universytet budivnytstva ta arkhitektury, 2015.

4. Klipkova O.I. Kreatyvnist' ta innovatsiynist' yak osnovni skladovi novoho vektora v upravlinni pidpryyemstvom / O.I. Klipkova // Naukovyy visnyk Mukachivs'koho derzhavnoho universytetu. Ser. Ekonomika. 2015. Vyp. 2(4). CH. 2. S. 76-79.

5. Litovchenko B. Zarodzhennya kreatyvnoyi shkoly menedzhmentu: retrospektyvnyy analiz [Tekst] / Bohdan Litovchenko // Zhurnal yevropeys'koyi ekonomiky. 2016. T. 15, № 4. S. 369-385.

6. Matsusyta Konosuke. Fylosofyya menedzhmenta $=$ The Heart of Management. - M.: Al'pyna Pablysher, 2016. - 188 s. - ISBN 978-5-9614-5683-7)

7. Svydruk I.I. Sotsial'no-ekonomichni aspekty kreatyvnoho menedzhmentu. Naukovyy visnyk NLTU Ukrayiny. Seriya Ekonomichna. 2018, t. 28, No 4. S. 108111. Svydruk, I.I. (2018). Socio-Economic Aspects of Creative Management. Scientific Bulletin of UNFU, 28(4), 108-111. https://doi.org/10.15421/40280420

8. http://www.me.gov.ua/Documents/List?lang=uk-UA\&id=be44a1a7- 69b34a77-a86a-447499abcdd6\&tag= Analitika \&isSpecial=true 